\title{
EWSR1/CREB1 Fusion Gene
}

National Cancer Institute

\section{Source}

National Cancer Institute. EWSR1/CREB1 Fusion Gene. NCI Thesaurus. Code C99249.

A fusion gene that results from a chromosomal translocation $\mathrm{t}(2 ; 22)(\mathrm{q} 34 ; \mathrm{q} 12)$ which

fuses the first 7 exons of the EWSR1 gene to the 5' side of exon 7 of the CREB1 gene.

This rearrangement is associated with angiomatoid fibrous histiocytoma and rare cases of malignant clear cell sarcoma of the soft tissue. 